\title{
9
}

\section{Environmentally Sustainable Development and Peace}

\author{
The Role of International Law
}

\author{
Christina Voigt
}

\begin{abstract}
Peace, development, and environmental protection are interdependent and indivisible. ${ }^{1}$

The environment is a crucial aspect of the right to peace... An area of particular relevance is climate change. ${ }^{2}$
\end{abstract}

\section{Introduction}

A safe, clean, and productive environment is conducive to peace and human security while environmental stress is both a cause and an effect of political tension and military conflict. The protection and preservation of the natural environment, integrity of ecological systems, and the survival of species are positive conditions for peace.

Yet, the connections between environmental issues and conflict are many and complex. Environmental factors themselves are rarely, if ever, the sole cause of violence. But natural resources and other environmental factors are linked to violent conflict in a variety of ways often obscured by more visible issues, such as ethnic tension and power politics. Conflicts can arise from the marginalization of sectors of the population and from ensuing violence. This occurs when political processes are unable to handle the effects of environmental stress resulting, for example, from floods, erosion, and desertification. Nations have often fought to assert or resist control over raw materials, energy supplies, land, river basins, sea passages, and other key environmental resources. Such conflicts are likely to increase as these resources become scarcer, the human population becomes larger, and competition for resources increases. 'Environmental stress can thus be an

1 Rio Declaration on Environment and Development, Rio de Janeiro, 1992, Principle 25.

2 HRC, 'Progress Report on the Right of Peoples to Peace', 22 December 2010, UN Doc. A/HRC/AC/6/CRP.3, para. 38. 
important part of the web of causality associated with any conflict and can in some cases be catalytic. Poverty, injustice, environmental degradation, and conflict interact in complex and potent ways. But the underlying causes often include the deterioration of the natural resource base and its capacity to support the population.' ${ }^{3}$ Conflicts may arise not only because of political and military threats to national sovereignty; they may derive also from environmental degradation and the pre-emption of development options.

The global environmental commons cannot be managed from any national centre: The nation-state is insufficient to deal with threats to shared ecosystems, to the biosphere, or to the atmosphere. States should therefore cooperate to preserve and protect the environment as a common interest through international law, based on the principle of sustainable and equitable use of natural resources, as well as other principles of international law. Threats to environmental security can only be dealt with by states' cooperative management and multilateral procedures and mechanisms. ${ }^{4}$

The sheer number of existing laws, principles, case law, regulations, standards and so on that address environmental protection already constitute a vast and complicated apparatus of international legal norms. Yet, environmental degradation and with it political stress and conflict continue despite such norm density. Existing environmental law is seemingly quite inadequate to the problem. But the solution lies not in more laws. What is urgently required is a more general realization that, in the conditions of the contemporary global situation, a truly sustainable international society must be built. What we need therefore is a shift in the quality of international laws, a shift that recognizes the fundamental importance of healthy ecological conditions. In this context, Mikhail Gorbachev noted that 'The root causes of the crises we are witnessing rest on outmoded theoretical concepts, values and institutions. Time has come for change, not incremental fixes." Such realization needs in fact a new vision of international law and international relations - a vision whereby a healthy environment is recognized as the foundation for peaceful human societies. After all, this is not just a question of ameliorating the tensions of human civilization but of survival.

This chapter seeks to explore ways in which cooperation for sustainable development can contribute to the maintenance of peace in the sense of diminishing potential for conflict. Environmental sustainability and healthy ecosystems should be considered a condition for building peace and environmental protection and cooperation a factor in peacemaking. As a peacemaking tool, the environment offers some useful-perhaps even unique-qualities that lend themselves to building peace and transforming conflict: environmental challenges ignore political boundaries, require a long-term perspective, encourage

3 'Our Common Future', Report of the World Commission on Environment and Development (1987), http://www.un-documents.net/ocf-11.htm\#I (accessed 16 June 2014).

4 WCED, 'Our Common Future'.

5 Green Cross, 'Green Cross Turns 20: The World at a Crossroads, Let's make the right choices for the future', http://www.gcint.org/green-cross-20-years (accessed16 June 2014). 
local and non-governmental participation, and extend community building beyond polarizing economic linkages. Where cooperation does take root, it may help to enhance trust, establish cooperative habits, create shared regional identities around shared resources, and establish mutually recognized rights and expectations. In this context, the present and potential role of public international law will be assessed. In particular, the international climate regime as an international agreement that purports sustainable resource use, conservation of ecosystems, sustainable management of commodities and cooperation in the management of a shared resource will be analysed for its potential to 'contribute to peace'. ${ }^{6}$

\section{The Challenges of Resource Scarcity and Abundance}

The complex relationship between peace and access to exploitable natural resources, whether they are abundant or scarce, is the subject of a large body of literature. Views on these issues differ and the discussion is contentious. In the following, only a brief overview of the various perspectives will be given.

\subsection{Peace and resource scarcity}

For many years there has been warning that 'Renewable resource scarcities of the next 50 years will probably occur with a speed, complexity and magnitude unprecedented in history ... We have come to understand that scarcities of renewable resources often produce insidious and cumulative social effects, such as population displacement and economic disruption. These events can, in turn, lead to clashes between ethnic groups as well as to civil strife and insurgency.' ${ }^{7}$ Despite this warning, some contend that resource scarcity per se does not suffice to bring about conflict. Conflict may occur when scarcity interacts with severe discrimination and the mobilization of rebel armies. ${ }^{8}$

One controversial example is the question of fresh water resources. The disputes over water rights at one level or another represent one of the principal causes of real or potential conflict in many different parts of the world. There are some who say that the great war of the next century could arise from a struggle for the control of fresh water, a resource increasingly under pressure from demographic

\footnotetext{
${ }^{6}$ For this reason, this chapter will not deal with the protection of the environment during armed conflict. For further references on this topic see Nordic Journal of International Law 82 (2013), in particular the contribution by Dieter Fleck, 'The Protection of the Environment in Armed Conflict: Legal Obligations in the Absence of Specific Rules', 7-20. See also Onita Das, Environmental Protection, Security and Armed Conflict: A Sustainable Development Perspective (Cheltenham: Edward Elgar, 2013).

7 Thomas F. Homer-Dixon, 'Environmental Scarcity and Global Security', Foreign Policy Association 300 (1993), 38-9.

8 Günter Baechler, Violence through Environmental Discrimination (Dordrecht: Kluwer Academic, 1999).
} 
expansion and economic activities. ${ }^{9}$ Others argue that resource scarcity leads to more cooperation and therefore less conflict. ${ }^{10}$

Experiences of cooperation and sustainable development in the area of management of supply and consumption of fresh water have led to the creation of mechanisms that aid users to define the norms for allocation, use, and transfer of water rights in a democratic process. In practice, this democratic process of resource allocation replaces previously existing conflict. ${ }^{11}$ Matz-Lueck argues that 'At the local level, the gun has been replaced by meetings between neighbours or committees who must learn to share a watershed. On a macro level, international accords and committees can serve as substitutes for wars. ${ }^{12}$

While resource scarcity can (but does not necessarily) lead in some cases to a situation of cooperation and diminished potential for conflict, it is difficult-and may in fact be dangerous - to generalize this position for all types of conflict over scarce natural resources.

\subsection{Peace and resource abundance ('resource curse')}

Natural resources pay for wars. Access to abundant natural resources is the fuel for many rebel armies. Unless rebel forces are financed from outside the country, they must generate income by operating business activities alongside their military operations. Rebel groups often hold their bases in rural areas and thus depend on the exploitation of primary commodities with high economic rents. Such 'conflict-commodities' often include ivory ${ }^{13}$, timber $^{14}$, gemstones, and minerals.

Moreover, dependence upon the existence and exploitability of natural resources is much higher in developing countries than in the 'industrialized world' and mismanagement, loss of access, and pollution may have grave socio-economic consequences. For many developing countries natural resources are the only valuable assets that safeguard the livelihoods of their peoples and offer opportunities for bilateral or international trade.

Yet, natural resources are rarely the sole cause of conflict. Religion, ethnicity, ideology, poor governance, and corruption are equally important factors. The linkages between resource wealth and conflict are complicated and

9 Laurence Boisson de Chazournes, Christina Leb, and Mara Tignino (eds.), International Law and Freshwater: The Multiple Challenges (Cheltenham: Edward Elgar, 2013).

${ }_{10}$ Nils Petter Gleditsch and Ole Magnus Theisen, 'Resources, the Environment and Conflict', in Handbook of Security Studies, ed. M. D. Cavelty and V. Mauer (Oxford: Routledge, 2010), 221-31.

${ }^{11}$ Nele Matz-Lueck, 'The Benefits of Positivism: The ILC's Contribution to the Peaceful Sharing of Transboundary Groundwater', in Source Peace through International Law: The Role of the International Law Commission: A Colloquium at the Occasion of its Sixtieth Anniversary, ed. Georg Nolte (Dordrecht: Springer, 2009), 129.112 Matz-Lueck, 'The Benefits of Positivism', 129.

13 See e.g. ivory fuelling conflict in the democratic republic of Congo: Jeffrey Gettleman, 'Elephants Dying in Epic Frenzy as Ivory Fuels Wars and Profits', New York Times, 3 September 2012, http://www.nytimes.com/2012/09/04/world/africa/africas-elephants-are-being-slaughtered-inpoaching-frenzy.html?pagewanted=all\&_r=0 (accessed 16 June 2014).

${ }^{14}$ See Wil de Jong, Deanna Donovan, and Ken-ichi Abe (eds.), Extreme Conflict and Tropical Forests (Dordrecht: Springer, 2007). 
'for every resource-rich country that has suffered from violent conflict, two or three have avoided it'. However, where resource wealth exists, unsustainable exploitation can often underpin and lengthen those conflicts that do arise from other causes. And conflicts themselves can often increase the rate of natural resource extraction. The challenge therefore is to devise ways to break these links and ensure that natural resources can be exploited without stimulating or funding conflict.

One example is the link between wildlife poachers, traffickers, and armed conflict in some regions of Africa. According to the WWF, over 20,000 elephants are killed each year for their ivory tusks, many of them in central African conflict zones. Rebel groups use the illegal ivory trade as a source to generate finances or otherwise to benefit from such trade.

The UN has been warning that ivory has become a major source of finance for armed groups and has led to the depletion of elephants in Central Africa. According to a UN experts' report S/2014/42 on the Democratic Republic of the Congo dated 23 January 2014, the slaughter of elephants in the Democratic Republic of the Congo 'is one of the most tragic consequences of years of war and poor governance. Driven by growing demand in Asia and increases in prices, poaching by armed groups and criminal networks has decimated elephant populations throughout eastern Democratic Republic of the Congo.'

In a novel move, the United Nations Security Council recently adopted two Resolutions, 2134 (2014) and 2136 (2014) on 28 January and 30 January 2014 respectively, on UN sanctions targeting armed rebel groups in the Central African Republic and the Democratic Republic of the Congo financed by the illegal exploitation of natural resources, including poaching and illicit wildlife trade. ${ }^{15}$ Individuals or entities involved will be subject to travel bans and asset freezes. With these resolutions, the Council de facto designated wildlife poaching and trafficking as threats to peace.

The new Security Council resolutions are certainly a prolongation and extension of previous practice of the Security Council on a positive concept of peace by recognizing wildlife poaching and trafficking as threats to peace. While the Council's motivation is anthropocentric (and not for the purpose of protecting animals from slaughter), a development towards a more holistic concept of peace has been set in motion. Peters states in this context: 'In the long run, however, an ecocentric approach to peace and security seems more appropriate to guarantee a sustainable peace for all living beings on earth. ... It is hoped that taking into account not only human security, but also the integrity of nature, the survival of species and the well-being of animals will be an increasingly relevant factor in global law and politics on peace and security.' ${ }^{16}$

15 CITES, 'UN sanctions on armed groups financed by poaching and illicit wildlife trade in the Central African Republic and the Democratic Republic of the Congo', http://www.cites.org/eng/ news/sundry/2014/20140203_un_sanctions.php (accessed 16 June 2014).

${ }_{16}$ Anne Peters, 'Novel practice of the Security Council: Wildlife poaching and trafficking as a threat to the peace', EJIL: Talk!, 12 Febuary 2014, http://www.ejiltalk.org/novel-practice-of-the-securitycouncil-wildlife-poaching-and-trafficking-as-a-threat-to-the-peace/ (accessed 16 June 2014). 
Another particular example is the one of 'conflict diamonds'. In a number of African countries, for example, Sierra Leone, the Democratic republic of Congo, Angola, Liberia, and Ivory Coast, diamonds are mined often by using forced child labour under horrendous labour standards. Moreover, these diamonds fuel armed conflicts in these regions, the activities of warlords and rebel movements aimed at overthrowing legitimate governments, and the illicit traffic in and proliferation of arms, especially small arms and light weapons. Diamonds are the 'currency of choice' for smugglers: they are portable, virtually untraceable, and universally valuable.

The extraction of and trade with conflict diamonds or 'blood diamonds' results in devastating impacts on the peace, safety, and security of people in affected countries and systematic and gross human rights violations. ${ }^{17}$

At the same time, high-value natural resources have the potential to promote and consolidate peace. In many post-conflict countries, revenues from resources such as oil, minerals, natural gas, gemstones, and timber are an integral part of the national economy. Lujala and Rustad note, 'When peace comes, the revenues from high value natural resources—when managed well—can help finance reconstruction and other vital peace-related needs. When mismanaged, however, resource revenues can undermine both economic performance and the quality of governance, and thereby increase the risk of violence. ${ }^{1}{ }^{18}$

The double-sided nature of valuable resources is exemplified in the blood diamond' example cited. Social outrage and strong critique (mostly of western NGOs) of the diamond trade involving blood diamonds led to a global debate on this issue which resulted in UN General Assembly Resolution 55/56(2000) calling on the international community to give urgent consideration to devising effective and pragmatic measures to address this problem. This resolution started the Kimberley process, a certification scheme where each shipment of rough diamonds is to be accompanied by a government-verified certificate that indicates the origin of each stone. This scheme is monitored by a working group, comprised of government, industry, and NGOs. Under the scheme, the trade between Kimberley members is restricted to certified non-conflict diamonds only. ${ }^{19}$

In Sierra Leone, together with the Kimberley Process Certification Scheme, the Diamond Area Community Development Fund aims to return revenues to communities and ensure that they have a say in their own development. One of the goals of the fund is to support local participation in decision-making about

${ }^{17}$ Jan Erik Wetzel, 'Targeted Economic Measures to Curb Armed Conflict? The Kimberley Process on the Trade in "Conflict Diamonds", in International Law and Armed Conflict, Challenges in the 21st Century, ed. Noëlle Quénivet and Shilam Shah-Davis (The Hague: T.M.C. Asser, 2012), 161ff. See also Kazumi Kawamoto, 'Diamonds in War, Diamonds for Peace: Diamond Sector Management and Kimberlite Mining in Sierra Leone', in High-Value Natural Resources and Post-Conflict Peacebuilding, ed. Pavivi Lujala and Siri Aaa Rustad (Oxford: Routledge, 2012), $121 \mathrm{ff}$.

18 Päivi Lujala and Siri Aas Rustad, 'High-Value Resources: A Blessing or Curse?', in eid. (eds.), High-Value Natural Resources and Post-Conflict Peacebuilding, 3ff. Also Paul Collier and Anke Hoeffler, 'High-Value Natural Resources, Development, and Conflict: Channels of Causation', in Lujala and Rustad (eds.), High-Value Natural Resources, 293ff.

19 For more information see: http://www.kimberleyprocess.com/ (accessed 16 June 2014). 
natural resources and development, and to thereby address the grievances of mining communities. These are essential means for preserving peace. ${ }^{20}$

In many cases, fuelling conflicts through access to rich natural resources is being made possible through unrestricted international trade. One of the main avenues therefore for stopping trade in conflict-prone commodities and for promoting the peaceful and sustainable management of high-value natural resources is through international trade law and investment law, dealing, for example with conditions for banning 'conflict-commodities', targeted economic sanctions, reducing investment opportunities in conflict-prone natural resources, etc. ${ }^{21}$ Even if this remains outside the scope of this chapter, it is important in this context to point to the important role of the WTO and other trade agreements: in order to promote peace, these regimes need to help building markets for sustainable, conflict-free goods — and restrict markets for the opposite. ${ }^{22}$

\subsection{Peace and (global) environmental change}

More recently, the 'resource abundance' and 'scarcity' paradigms have been joined by one stressing global environmental change as a driver of social unrest. So noted, for example, the UN High-level Panel on Threats, Challenges and Change, that environmental degradation per se is a threat to security. ${ }^{23}$

Global change discourses stress the idea that growth is bounded by limits. But in this case the limits are not scarce resources and commodities, but rather the disruption of global-scale environmental services and ecological functions

${ }^{20}$ Kawamoto, 'Diamonds in War, Diamonds for Peace', 131-2.

21 The concern of WTO incompatibility with this scheme was addressed by the adoption of a waiver for conflict diamonds under Art. IX:3 Marrakesh Agreement Establishing the WTO_an example that targeted economic measures under international law (i.e. WTO law) can contribute to peace. For further discussion see the chapter by Ole Kristian Fauchald in this volume. See also Joost Pauwelyn, 'WTO Compassion or Superiority Complex?: What to Make of the WTO Waiver for "Conflict Diamonds", Michigan Journal of International Law 24 (2003), 1177-207.

22 Duncan Brack, 'Building Markets for Conflict-free Goods', in Trade, Aid and Security, An Agenda for Peace and Development, ed. Oli Brown, Mark Halle, Sonia Peña Moreno, and Sebastian Winkler (Oxford: Earthscan, 2007), 92ff.

${ }_{23}$ Report of the High-level Panel on Threats, Challenges and Change, 'A More Secure World: Our Shared Responsibility' (United Nations, 2004), http://www.un.org/en/peacebuilding/pdf/historical/hlp_more_secure_world.pdf (accessed 16 June 2014): '22 . ... Disease and poverty ... are connected to environmental degradation; climate change exacerbates the occurrence of such infectious disease as malaria and dengue fever. Environmental stress, caused by large populations and shortages of land and other natural resources, can contribute to civil violence. ... 53. Environmental degradation has enhanced the destructive potential of natural disasters and in some cases hastened their occurrence. The dramatic increase in major disasters witnessed in the last 50 years provides worrying evidence of this trend. More than two billion people were affected by such disasters in the last decade, and in the same period the economic toll surpassed that of the previous four decades combined. If climate change produces more acute flooding, heat waves, droughts and storms, this pace may accelerate. 54. Rarely are environmental concerns factored into security, development or humanitarian strategies. Nor is there coherence in environmental protection efforts at the global level. Most attempts to create governance structures to tackle the problems of global environmental degradation have not effectively addressed climate change, deforestation and desertification. Regional and global multilateral treaties on the environment are undermined by inadequate implementation and enforcement by the Member States.' 
that support life on earth. These services include climate regulation, water filtration and purification, nutrient cycling, atmospheric screening of ultraviolet radiation, and preservation of biological diversity. Scientists have just begun to understand the interconnections among land, oceans, atmosphere, and biosphere and have come to see the environment as a single, interconnected, living system. Accordingly, different conceptions about the link between environmental protection, the prevention of pollution and ecological degradation on the one hand and peace on the other developed. ${ }^{24}$

A narrower, traditional discourse looks at the link between environmental degradation and large-scale violence by aiming to adapt traditional military and intelligence tools to counter these threats. ${ }^{25}$

A broader conceptualization of the 'environmental foundation(s) of peace' leaves the use of force and military means aside. In this way, peace can be thought of as a continuum ranging from the absence of violent conflict to the inconceivability of violent conflict. ${ }^{26}$ Conca, a prominent scholar in the field of international relations and environmental peace-building, has challenged dominant constructions of environmental scarcity, ecologically induced violence, and state failure by stressing the cooperative potential rather than violent inevitabilities, social transformation rather than social control, and peace rather than militarization. In essence, rather than seeking to pinpoint the environmental triggers of conflict, he is seeking to pinpoint the cooperative triggers of peace that shared environmental problems might make available. ${ }^{27}$

Such broader conception is referred to by some as 'ecological security', which 'means a much more fundamental rethinking of what we mean by security in a tightly couples world system. ... One implication of this view is the need to shift social (and economic) resources away from traditional military means of defense (and attack) and toward preventive economic and social measures. ${ }^{28}$ In other words, the means of ensuring peace is through increased environmental protection through cooperation.

A definition of peace (and development) must therefore necessarily take into consideration aspects of environmental protection and sound environmental management. This involves typical transboundary issues, for example pollution of rivers or transboundary air pollution, as well as global threats to the biosphere and the atmosphere, such as climate change and the loss of biological diversity. All these problems may have significant consequences for states and their populations. Transboundary or global environmental risks also have in common that

${ }^{24}$ Ken Conca, 'The Case for Environmental Peacemaking', in Environmental Peacemaking, ed. Ken Conca and Geoffrey D. Dabelko (Baltimore: Johns Hopkins University Press, 2002), 1ff.; and Ken Conca and Geoffrey D. Dabelko, 'The Problems and Possibilities of Environmental Peacemaking', Environmental Peacemaking, $220 \mathrm{ff}$.

25 John Deutsch, former director of the US Central Intelligence Agency, speech to the Los Angeles World Affairs Council, Los Angeles, 25 July 1996.

${ }_{26}$ See Cecilia Bailliet and Kjetil M. Larsen, 'Introduction' to this volume.

27 Bailliet and Larsen, 'Introduction'.

28 Conca, 'The Case for Environmental Peacemaking', 2. 
they can only effectively be addressed if states cooperate on a bilateral, regional, or global level. Co-operation is essential to the sustainable, wise, and equitable use of resources and for preserving their base for present and future generations. This helps ultimately to avoid the outbreak of internal and transboundary unrest, hostilities, and conflict.

\section{Sustainable Development and Peace}

Development depends crucially upon peace-and peace depends upon development. But not all kinds of development are equally conducive to peace. Economic, social, and ecological development are increasingly interdependent-and development in order to last and to be just must be based on all three 'pillars'. This idea is aptly captured in the concept of sustainable development.

Examples of current global trends which present formidable challenges to the achievement of both peace and sustainability include the problem of population growth above the carrying capacity of the known natural resource base and the predominant technology; mounting pressure on diminishing quantities of fresh water and topsoil; disputed jurisdiction over territorial areas containing strategic resources; the added impacts of climatic change to already vulnerable people and social groups; the destabilizing impact of widespread poverty and increasing social inequality; and a rising flow of migrants fleeing war, famine, natural hazards, and other vestiges of political, social, and economic breakdown. ${ }^{29}$

It is thus ever more urgent that the nexus between development and environmental protection in the context of sustainable development must be strengthened if peace is to be maintained or achieved. The nexus between sustainable development, environmental protection, and peace was aptly recognized in Article 25 of the 1992 Rio Declaration on Environment and Development, which states: 'Peace, development, and environmental protection are interdependent and indivisible. ${ }^{30}$

Sustainable development has been defined as 'development that meets the needs of the present, without compromising future generations to meet their own needs. ${ }^{31}$ Its normative content is defined by the reconciliation of present and future economic, social, and environmental interests within the limits set by certain essential ecological functions. ${ }^{32}$ Sustainable development also implies that ecological functions exist that are indispensable for a durable and equitable human society. Natural ecosystems provide the critical basis for all human societies. For a long time the fact has remained uncontested that societies derive a wide array of important life-support and economic benefits from the ecosystems

29 Brack, Trade, Aid and Security, $4 \mathrm{ff}$.

30 Report of the United Nations Conference on Environment and Development, 'Rio Declaration on Environment and Development' (12 August 1992), UN Doc. A/CONF.151/26 (Vol. I), principle 25.

31 WCED, 'Our Common Future'.

32 Christina Voigt, Sustainable Development as a Principle of International Law-Resolving Conflicts between Climate Measures and WTO Law (Leiden: Martinus Nijhoff, 2009). 
in which they exist. ${ }^{33}$ In recent years an understanding across various disciplines has crystallized that human development, security, peace-humanity per sedepends on healthy ecological functions and conditions. Sustainable development requires nations to set out and implement concrete goals that submit all other activities to the protection of those essential natural conditions on which human societies depend.

This was something the World Commission called for and it is essential still. 'At a minimum', the Commission stated, 'sustainable development must not endanger the natural systems that support life on Earth', adding that there were objective limits to what nature could bear. ${ }^{34}$ Yet, the 2012 Global Environmental Outlook 5 provided proof of the deterioration of a large number of essential ecosystem services and cautioned that if humanity does not urgently change its ways, several critical thresholds may be exceeded, beyond which abrupt and generally irreversible changes to the life-support functions of the planet could occur.' ${ }^{35}$

Sustainable development with the purpose of securing peace demands that economic and social development is pursued while ultimate ecological thresholds are respected. These thresholds define the ecological constraints for human activities and development, without which development cannot be sustainable.

These ecological limits — or planetary boundaries — are not unknown. There is a wealth of scientific data and knowledge. ${ }^{36}$ These limits, defined on a planetary scale, need to be broken down to state level as obligations under international law and further defined at sub-state levels, such as regional, municipal, local, city, village, even individual levels. Science already has the answers. What is missing, however, is the willingness of states and sub-state actors to act accordingly. The current condition of the environment is not caused by failure or accident. It is wanted.

When designing new and interpreting existing international law, ecological limits to development have to be recognized, and these limits defined and included in the legal framework by clear, comprehensive, implementable, and reviewable rules concerning, for example, air, soil, biodiversity, and water quality standards.

Sustainable development as a guiding concept for international law does not and cannot (necessarily and under all circumstances) mean giving equal weight to all (economic, social) concerns. Sustainable development is eventually about making compromises. But these compromises have to be sustainable

\footnotetext{
33 An ecosystem is a dynamic complex of plant, animal, and micro-organism communities and the non-living environment interacting as a functional unit.

34 WCED, 'Our Common Future', 44-5.

35 'World Remains on Unsustainable Track Despite Hundreds of Internationally Agreed Goals and Objectives', UNEP New Centre, 6 June 2012, http://www.unep.org/newscentre/default.aspx? DocumentID=2688\&ArticleID=9158 (accessed 18 February 2013).

36 See e.g. Millennium Ecosystem Assessment, 'Living Beyond Our Means: Natural Assets and Human Well-Being' (March 2005), available at: http://www.maweb.org/en/index.aspx (accessed 15 June 2014); J. Rockström et al., 'Planetary Boundaries: Exploring the Safe Operating Space for Humanity', Ecology and Society 14 (2009), 32.
} 
and-even more crucially - the sum of the compromises has to be sustainable. Because it will be the sum of all measures that gives an indication of their sustainability.

By constituting these essential ecological conditions as a de minimis requirement of sustainable development, the concept inhabits a non-derogable ecological core. At this core lie the 'unchanging and universal laws of nature' with which human activities need to be brought into and kept in harmony. ${ }^{37}$ This core must be used as a point of departure and a 'principled priority' guide on how otherwise widely divergent priorities relate to each other. Thus, when integrating the components of sustainable development, priority must be given to protecting fundamental, natural life-supporting systems in principle and in practice. This aspect of sustainable development is the most fundamentalthe one without which the concept becomes indeterminate and eventually meaningless.

There has developed over the three decades an understanding and increasing appreciation that environmental degradation undermines peace. It is also ever clearer that the nexus between development and environmental protection in the context of sustainable development must be strengthened if peace is to be maintained or achieved.

'Exploitation of the Earth's resources', Judge Weeramantry noted,

without regard to the future and the destruction of the environment are among the principal contemporary causes of global tension. Herein lie the seeds of future conflicts and sustainable development is an insurance against those conflicts and possibly wars of the future.... True peace is impossible without justice. A principal element of justice is economic justice. Economic justice is impossible without sustainable development. Sustainable development is thus an important prerequisite of peace. If peace is an indispensable object of international law, sustainable development is indispensable to the attainment by international law of its most important goal. ${ }^{38}$

The relationship between peace and sustainable development is thus one of mutual dependence: unsustainable development drives conflict, while conflict makes sustainable development impossible. ${ }^{39}$ It is in this understanding that the World Commission on Environment and Development summarized clearly in its final report 'Our Common Future', 'Certain aspects of the issues of peace and security bear directly upon the concept of sustainable development. Indeed, they are central to it. ${ }^{\prime 40}$

37 This is what the WCED noted early on: 'Human laws must be reformulated to keep human activities in harmony with the unchanging and universal laws of nature.' WCED, 'Our Common Future', 330.

${ }_{38}$ Christopher Weeramantry, Universalising International Law (Leiden: Martinus Nijhoff, 2004), 446. See also Christopher Weeramantry and John Burroughs, International Law and Peace: A Peace Lesson, A web-based part of Hague Appeal for Peace, Peace Lessons from Around the World, http:// lcnp.org/global/Law_and_Peace.pdf (accessed 16 June 2014).

39 Onita Das, Environmental Protection, Security and Armed Conflict, A Sustainable Development Perspective (Cheltenham: Edward Elgar, 2013).

40 WCED, 'Our Common Future', 290. 


\section{International Environmental Law and Peaceful Cooperation}

Law is a governing instrument for the international community of states. It is an approach to overcome anarchy and chaos-both on the national and international level. International law's main purpose was-and is - to achieve peace between states in an attempt to tame their absolute sovereignty which includes the use of force as an inherent component.

The collective pressure that states currently put on natural resources and ecological systems is starting to exceed—and partly already exceeding-ecological thresholds. ${ }^{41}$ This development raises inconvenient questions as to the sustainability of the current economic and political model pursued by most states. It has become clear that significant political and legal interventions are necessary to realign development with the limits set by those thresholds.

Modern international law has to deal with a far wider variety of challenges than those deriving exclusively from forcible intervention in the affairs of other states. Various pressures of a modern, globalized world are forcing the international community of states (as the 'legislators' of international law) to think anew and recognize a more collectively oriented international legal system; socially oriented in the sense of recognizing international actors in their capacity to act in concert for the 'common good of all'. Global environmental threats, such as ozone depletion, global climate change, loss of biodiversity, and advancing desertification damage not only individual states, but the world at large. Pollution knows no national boundaries, nor does the problem of a changing global climate. The impact of climate change on the stability of the global community is expected to be dire. The challenges facing international law to construct equitable and cooperative global responses to shared problems are already tangible. ${ }^{42}$

Principles are abounding in international environmental law that aim to protect and preserve both common and states' environmental interests based on equity and fairness. These include, for example, the prohibition of significant environmental harm to the territory of other states or of areas beyond national jurisdiction, ${ }^{43}$ the principle of sustainable development, ${ }^{44}$ the principle of common but

41 See e.g. OECD, 'OECD Environmental Outlook to 2050: The Consequences of Inaction' (March 2012), http://www.oecd.org/environment/indicators-modelling-outlooks/ oecdenvironmentaloutlookto2050 theconsequencesofinaction.htm (accessed 16 June 2014); UNEP, Global Environmental Outlook 5, http://www.unep.org/geo/geo5.asp (accessed 16 June 2014); Millennium Ecosystem Assessment 2005, and Rockström et al., 'Planetary Boundaries', 32.

${ }^{42}$ See X. Wang, 'Sustainable International Climate Change Law: A Future Legal Research Agenda', in Sustainable Development Law: Principles, Practices and Prospects, ed. by Marie-Claire Cordonier Segger and Ashfaq Khalfan (New York: Oxford University Press, 2004), 353-4.

43 'Report of the United Nations Conference on the Human Environment' (Stockholm Declaration), Stockholm (5-16 June 1972), UN Doc. A/CONF.48/14/Rev.1, principle 21; Rio Declaration, principle 2. The ICJ in its Advisory Opinion in the Legality of the Threat or Use of Nuclear Weapons, stated: 'The existence of the general obligation of States to ensure that activities within their jurisdiction and control respect the environment of other States or of areas beyond national control is now part of the corpus of international law relating to the environment.' (1995) ICJ reports $347 . \quad 44$ Voigt, Sustainable Development as a Principle of International Law. 
differentiated responsibility and respective capabilities, the principle of common heritage of mankind, ${ }^{45}$ the precautionary principle that deals with decision-making in the face of scientific uncertainty as well as the principle that indicates that the costs of pollution should be borne by the person, state, or company responsible for causing the pollution. ${ }^{46}$

Moreover, issues of universal importance such as conservation of biological diversity, mitigation of dangerous anthropogenic climate change, and transboundary movement of hazardous substances are nowadays subject to a large number of multilateral environmental agreements. Their own institutions, reporting requirements, exchange of information, and regular meetings of the parties enhance cooperation. Those states who collaborate to draft common plans for the management of natural resources, a joint framework based on substantive obligation and finance obligations in accordance with the principle of common but differentiated responsibility and respective capabilities, who rely on the procedures in place to address non-compliance and disputes should they arise, have all taken necessary safeguards to prevent and peacefully settle conflicts. ${ }^{47}$ It is for these reasons that the United Nations Environment Programme (UNEP) is engaged in environmental cooperation for peace-building (ECP); noting on their website: 'UNEP aims to use environmental cooperation to transform the risks of conflict over resources into opportunities for stability and peacebuilding in war-torn or fragile societies. ${ }^{3} 8$

The cooperation needed, in particular to tackle the climate change challenge, is, in Judge Weeramantry's words, 'not merely passive cooperation, but rather active cooperation. If we are to save our global inheritance, we must do so actively. We need, for this purpose, to be willing to surrender some part of sovereignty to the rest of the world, accepting common guidance by the global community. ${ }^{349}$ In this globalized and interdependent world, the recognition has therefore grown that states need to cooperate-to actively engage with each other-to stand a chance of addressing global challenges of an unprecedented nature.

For enhancing international laws potentially conducive to peace, legal regimes are necessary that support sustainable resource management, a high degree of environmental and human rights protection, and the building of markets for sustainable, conflict-free goods_-and trestriction of markets for those that are not. Sustainable development requires a transformation in the way in which economic development is pursued. It requires first and foremost, that economic activities be guided by ecological boundaries. Its central premise is that human activity must

45 P. Taylor, 'Common Heritage of Mankind Principle', in Berkshire Encyclopaedia of Sustainability, iii. The Law and Politics of Sustainability, ed. Klaus Bosselmann, Daniel Fogel, and J. B. Ruhl (Great Barrington: Berkshire, 2011), 64-9.

46 See Sumudu A. Attapattu, Emerging Principles of International Environmental Law (Leiden: Martinus Nijhoff, 2006); Nicolas de Sadeleer, Environmental Principles: From Political Slogans to Legal Rules (New York: Oxford, 2005).

47 Matz-Lueck, 'The Benefits of Positivism', 137.

48 'Disaster and Conflicts', UNEP, http://www.unep.org/disastersandconflicts/Introduction/ ECP/tabid/105948/Default.aspx (accessed 16 June 2014).

49 Segger and Khalfan, Sustainable Development Law, p. xi. 
not exceed the carrying capacity of planetary ecosystems. This premise needs to be reflected in the law.

\section{Climate Change and Peaceful Cooperation for Sustainable Development: The Example of the UN Climate Change Regime}

Can cooperation with the purpose of sustainable development render violent conflict less likely? ${ }^{30}$ Much more research might be necessary to give a conclusive answer to this question. We will nevertheless attempt to sketch out one area of international law where a relationship between cooperation and mutual dependence is emerging: the international regime for addressing climate change.

From the outset we can state that not just cooperation per se is important as a factor for peace. Depending on the resource or environmental issue at stake, the form and content of cooperation might differ. The closer and more interdependent' the cooperation between states is, the greater might be the potential for positive side effects from that cooperation that can create positive synergies for peace.

\subsection{Means of cooperation}

Cooperation between states flows from the principle of 'good-neighbourliness' as included in Article 74 of the UN Charter. Together with the prohibition of significant transboundary harm-based on the maxim sic utere tuo at alienum non laedas - good neighbourliness in environmental matters has led to the development and application of rules promoting international environmental cooperation. ${ }^{51}$ The principle of environmental cooperation is reflected in principle 24 of the Stockholm Declaration as a general political commitment and in principle 27 of the Rio Declaration stating that 'States and people shall co-operate in good faith and in a spirit of partnership in the fulfilment of the principles embodied in this Declaration and in further development of international law in the field of sustainable development.' Since then, the principle is reflected in many treaties and is supported by state practice..$^{52}$

The principle of environmental cooperation is affirmed in virtually all international environmental agreements. ${ }^{53}$ The general obligation to cooperate has been translated into more specific techniques to ensure the sharing of information and participation in decision-making. Exchange of information, notification,

\footnotetext{
50 Segger and Khalfan, Sustainable Development Law, 9.

51 Philippe Sands and Jacqueline Peel, Principles of International Environmental Law (3rd edn.; Cambridge: Cambridge, 2012), 203.

52 Sands and Peel, Principles of International Environmental Law, 203.

53 See e.g. 1982 United Nations Convention on the Law of the Sea (UNCLOS), Arts. 123 and 197; 1991 Alpine Convention, Art. 2(1); 1985 Vienna Convention on the Protection of the Ozone Layer, Art. 2(2); 1992 Convention on Biological Diversity, Art. 5.
} 
consultation, and other forms of cooperation are examples of the implementation of the obligation of environmental cooperation. More specific cooperation commitments include rules on transboundary environmental impact assessments, ${ }^{54}$ rules that ensure that neighbouring states or states importing hazardous substances receive all necessary information through required information exchange, consultation, and notification, and that there is the option to ban such imports, ${ }^{55}$ and also rules on the provision of emergency information, and the transboundary enforcement of environmental standards.

State practice on environmental cooperation is further reflected in the decisions and awards of international courts and tribunals, including, for example, the Lac Lanoux case, ${ }^{56}$ the MOX plant case, ${ }^{57}$ the Gabcikovo-Nagymaros project case, and the Pulp Mills case. ${ }^{58}$

In international environmental law, cooperation is thus a central principle in order to prevent disputes, to provide timely notification of plans to carry out or permit activities that may entail transboundary or international interference or environmental harm, or a significant risk thereof, and to engage in good faith consultations to arrive at a fair and equitable resolution of the situation.

\subsection{Cooperation in the international climate regime}

\subsubsection{Climate change and conflict}

A very opportune example of international cooperation is the UN climate regime. Mitigation of and adaptation to climate change are very urgent issues, which if not tackled might have severe security implications. ${ }^{59}$

Without resolute counteraction, the effects of climate change are likely to exceed many societies' adaptive capacities to internal or external stresses within the coming decades. If not halted, the likelihood sharply increases that climate change will draw ever deeper lines of division and conflict in international relations as well as in national affairs. It has the potential to trigger numerous conflicts between and within countries over the distribution of resources (especially water and land), over the management of migration, or over compensation payments between the countries mainly responsible for climate change and those countries most affected by its destructive effects. ${ }^{60}$

\footnotetext{
54 Convention on Environmental Impact Assessment in a Transboundary Context (Espoo, 1991).

55 See e.g. the advanced informed agreement procedure in Art. 6 of the Cartagena Protocol on Biosafety to the Convention on Biological Diversity (Montreal, 2000).

56 Lac Lanoux arbitration (France v. Spain) (1957) 24 ILR 101.

57 The MOX Plant case (Ireland v. United Kingdom) (Interim Measure) (2002) 41 ILM 405.

58 Gabcikovo-Nagymaros (Hungary v. Slovakia) [1999] ICJ Reports 7; Pulp Mills on the River Uruguay (Argentina v. Uruguay) (Judgment) [2010] ICJ Rep 2010 p. 14.

59 Christina Voigt, 'Security in a "Warming World": Competences of the UN Security Council for Preventing Dangerous Climate Change', in Security: A Multidisciplinary Normative Approach, ed. Cecilia M. Bailliet (Leiden: Brill, 2009), 291-312.

${ }^{60}$ German Advisory Council on Global Change (WGBU), World in Transition: Climate Change as a Security Risk (London: Earthscan, 2007), 23.
} 
If, by 2020, political efforts to limit temperature increases to $2{ }^{\circ} \mathrm{C}$ have failed, the international community must prepare itself to deal with climate-related conflicts. If this temperature threshold is crossed, the likelihood of conflicts increases significantly. Such conflicts include disputes over resources (based on reduction of arable land, widespread shortage of freshwater, diminishing food and fish stocks, increased flooding and prolonged droughts) and over loss of territory, border clashes, ${ }^{61}$ situations of fragility and increasing instability in weak or failing states, and tensions over energy supply. ${ }^{62}$ The Intergovernmental Panel on Climate Change (IPCC) warns in its most recent report that climate change over the twenty-first century will have a significant impact on forms of migration that compromise human security. For example, it indirectly increases the risks from violent conflict in the form of civil war, inter-group violence, and violent protests by exacerbating well-established drivers of these conflicts such as poverty and economic shocks. A warming climate will place the world under enormous strain, forcing mass migration, especially in Asia, and thereby increasing the risk of violent conflict. ${ }^{63}$

Small island states and other places highly vulnerable to sea-level rise face major challenges to their territorial integrity. Some 'transboundary' impacts of climate change, such as changes in sea ice, shared water resources, and migration of fish stocks have the potential to increase rivalry among states. ${ }^{64}$

The High-level Panel on Threats, Challenges, and Change noted climate change as one of the global threats to security. The panel stated,

In order to address problems of climate change modern economies need to reduce their dependence on hydrocarbons and should undertake a special effort to devise climate-friendly development strategies. Member States should place special attention on the development of low-carbon energy sources, including natural gas renewable power and nuclear power, and should place special emphasis on the development of low-greenhouse-gas technologies ... States should provide incentives for the further development of renewable energy sources and begin to phase out environmentally harmful subsidies, especially for fossil fuel use and development. ${ }^{65}$

${ }^{61}$ In this context, the High Representative and the European Commission to the European Council note: 'Scientists project major changes to the landmass during this century. Receding coastlines and submergence of large areas could result in loss of territory, including entire countries such as small island states. More disputes over land and maritime borders and other territorial rights are likely. There might be a need to revisit existing rules of international law, particularly the Law of the Sea, as regards the resolution of territorial and border disputes. A further dimension of competition for energy resources lies in potential conflict over resources in Polar Regions which will become exploitable as a consequence of global warming. Desertification could trigger a vicious circle of degradation, migration and conflicts over territory and borders that threatens the political stability of countries and regions.' 'Climate Change and International Security', Paper from the High Representative and the European Commission to the European Council, S113/08 (14 March 2007), 4.

62 'Climate Change and International Security', 2-5.

${ }_{63}$ See Tom Bawden, 'Official prophecy of doom: Global warming will cause widespread conflict, displace millions of people and devastate the global economy', The Independent, 18 March 2014, http:/www.independent.co.uk/environment/climate-change/official-prophecy-ofdoom-global-warming-will-cause-widespread-conflict-displace-millions-of-people-and-devastate-t he-global-economy-9198171.html (accessed 16 June 2014). A draft of the final version of the IPCC report was leaked to the magazine.

${ }_{65}$ Report of the High-level Panel on Threats, Challenges and Change, 'A More Secure World', 99. 
However, there remains a certain degree of uncertainty as to the exact impacts of climate change on the local levels. The simple fact is that nobody really knows with any degree of precision what climate change will mean for human population movement and distribution. ${ }^{66}$ This is unsurprising; the science of climate change is complicated. In addition, the interconnections between environmental conditions, societies with widely differing resources and varied capacities to adapt to external shocks, and the resulting conflict potential add a high degree of complexity. In the absence of absolute scientific certainty about the social and political impacts of climate change, the phenomenon is best viewed as a threat multiplier which exacerbates existing trends, tensions, and instability. In any event, preventing dangerous climate change means reducing the likelihood of climate-related individual and international security threats. Therefore, a proactive climate protection policy must be in place with the aim of significantly reducing greenhouse gas emissions in order to keep global warming as close to the $2{ }^{\circ} \mathrm{C}$ limit as possible. At the same time, strategies for adaptation to unavoidable climate change must be intensified and oriented towards the type of climate impact scenario that can be expected. The greater the delay in commencing efforts to mitigate climate change and to adapt to its impacts, the more expensive such efforts will become. Development that leads to missed opportunities to protect the climate will entail far higher costs—including instability and conflicts - than a reference scenario in which compliance with the $2{ }^{\circ} \mathrm{C}$ target is achieved. ${ }^{67}$

\subsubsection{Climate change and development cooperation}

At its core, climate change regime is in reality a 'development regime': the effective reduction of greenhouse gas emissions requires transformative changes of (all) economies. This is only possible if development plans are aligned with the scientific limits set to remain within global temperature increases of $2{ }^{\circ} \mathrm{C}$. Greenhouse gas emissions come from all economic sectors. Whole sectors, whole economies need to be transformed to become low-carbon intensive or even carbon-neutral. The climate change regime will significantly define the development path of all its member states.

However, not all states have contributed equally to the problem of the increasing greenhouse gas concentrations in the atmosphere, nor do they possess the same means and capacities to address the reduction of greenhouse gas emissions or to adapt to the effects of climate change. While some states may have contributed minimally to the problem, they may become more seriously affected than others. For that reason it is imperative to cooperate across the board on finding a fair and effective way of burden-sharing and differentiating between states' obligations

${ }^{66}$ Report of the High-level Panel on Threats, Challenges and Change, 'A More Secure World', 99.

${ }_{67}$ The National Archives, HM Treasury, 'Stern Review on the Economics of Climate Change', 2006, http://webarchive.nationalarchives.gov.uk/20130129110402/ http://www.hm-treasury.gov. uk/stern_review_report.htm (accessed 16 June 2014). 
and entitlements. ${ }^{68}$ It is for this reason that the UN Framework Convention calls for the 'widest possible cooperation by all countries and their participation in an effective and appropriate international response, in accordance with their common but differentiated responsibilities and respective capabilities and their social and economic conditions'. ${ }^{69}$

\subsubsection{The issue of global equity}

The design of an equitable international climate response poses a paramount challenge to the traditional structure of public international law, which is based on the sovereign equality of states. States are supposed to be treated equally: as a starting point the same rights and duties apply to all. There is, however, growing understanding that in order to achieve equal treatment of states, their differences must be taken into account. Differentiation and positive discrimination (e.g. through affirmative action) is necessary in order to treat states that are different on an equal basis.

An equitable approach to the climate challenge is often understood as an approach based on the principle of common but differentiated responsibility and respective capabilities (CBDRRC) as mentioned in Article 3 UNFCCC, which says that 'parties should act to protect the climate system on the basis of equity and in accordance with their common but differentiated responsibilities and respective capabilities'.

This principle has so far mainly been used by major developing countries as an argument for demanding from developed countries an acknowledgement of their historic contributions to the increased concentration of greenhouse gases in the atmosphere and to act responsibly by taking the lead in climate mitigation and finance. ${ }^{70}$ The other side of this argument is that developing countries-having historically contributed marginally to the current concentrations-should not be required to take on mandatory commitments to reduce their GHG emissions. Accordingly, differentiation has so far been along the dividing line of 'developed' and 'developing' states and according to historical contributions of developed countries to environmental degradation, as well as the capability of developed countries to engage in cost-intensive environmental mitigation action. These factors (criteria) have led to substantively stronger obligations of developed countries, with developing countries having milder or no obligations as well as entitlements to significant financial transfers and the contribution of of capacity, technology, and know-how from developed countries. Based on these criteria, 'positive discrimination' in favour of developing countries has led to highly

\footnotetext{
${ }^{68}$ See Geir Ulfstein and Christina Voigt, 'Rethinking the Legal Form and Architecture of a New Climate Agreement', in Toward a New Climate Agreement: Conflict, Resolution and Governance, ed. Todd L. Cherry, Jon Hovi, and David M. McEvoy (London: Routledge, 2014), 183-98.

${ }^{69}$ United Nations Framework Convention on Climate Change (UNFCCC), UN 1992, preamble, item 6., See also Art. 3, para. 1; Art. 4 paras. 2(a) and 7.

70 UNFCCC, Arts. 3, 4.2, and 4.7.
} 
asymmetric environmental obligations coupled with mechanisms for capacity building and the transfer of financial resources and technology as well as compliance assistance.

However, the world today is characterized by disparities in resources and capabilities in different ways than applied 30 years ago. The antagonistic dividing line between developed and developing countries is becoming increasingly blurred. Each of the two groups, if they can be identified at all, ${ }^{71}$ is no longer homogenous but marked by stark internal differences. In addition, the international landscape undergoes changes and fluctuations. Any attempt at categorization might be insufficient to capture such dynamism. Some developing countries that were marginally contributing to the climate challenge in 1992, count nowadays among the top global polluters. For that reason there need to be more differentiation ${ }^{72}$ and differentiation should be flexible and dynamic and only granted on a temporary basis.

The question is thus how to reflect the different 'situations' of states and their dynamic development in the new agreement. The change in the world between 1992 and 2014 and beyond tells us that such differentiation cannot be static; it must be based on dynamic and flexible parameters that allow the structure of the agreement to evolve as the world evolves. Such a solution can be found only through negotiations and cooperation.

While so far, only one particular interpretation of the CBDRRC principle (i.e. differentiation based on historic contributions) has dominated the climate negotiations, the time has come for more countries to put forward their (evolved) understanding of that principle. A number of countries have recently come forward with their understanding that the CBDRRC principle is reflective of certain dynamism in the climate regime as it is not set in stone, but evolves over time. In the ongoing climate negotiations, many Parties therefore observed 'that the principles [of the Convention] are not rigid, and should be applied in a dynamic and evolving manner taking into account national circumstances, changing economic realities and levels of development. ${ }^{73}$ 'Principles ... need to be forward-looking and take into account what the world might look like in 2020.'74 Some Parties stated also that the application of the Convention 'should be adapted in order to improve its vitality and relevance in the modern world and in order to enable it to become a modern instrument to address climate change. It was pointed out that

71 According to the United Nations Statistics Division, "There is no established convention for the designation of "developed" and "developing" countries or areas in the United Nations system.' See 'Composition of macro geographical (continental) regions, geographical sub-regions, and selected economic and other groupings', UNSD (n. C), revised 31 October 2013, http://unstats. un.org/unsd/methods/m49/m49regin.htm\#ftnc (accessed 16 June 2014).

72 See also Joost Pauwelyn, 'The End of Differential Treatment for Developing Countries? Lessons from the Trade and Climate Regimes', RECIEL 22 (2013), 29-41, who argues for more differentiation and further subdivisions.

73 'Summary of the Roundtable under Workstream 1, ADP1, part 2, Doha, Qatar, NovemberDecember 2012', Ad Hoc Working Group on the Durban Platform for Enhanced Action, Note by the Co-Chairs (7 February 2013), 3, http://unfccc.int/resource/docs/2012/adp1/eng/Ginfsum.pdf (accessed 23 June 2014).

74 'Summary of the Roundtable under Workstream 1', 3. 
the Convention has evolved, and will continue to evolve over time, and thus the manner in which the principles apply also needs to evolve. ${ }^{75}$

Yet, finding reliable but flexible and dynamic criteria or means to defining various (groups of) 'equals', and allocating rights and responsibilities accordingly, is a task where countries need to talk to each other and to cooperate, and such cooperation, for as long as it lasts, may prevent them from engaging in rivalry against each other.

\subsubsection{Cooperation and the example of REDD-plus}

One particular area where the climate negotiations have advanced significantly is the protection of forests in developing countries for the purpose of reducing emissions from deforestation and forest degradation. Tropical timber has for a long time been a commodity on which income-poor countries depended, but which also has fuelled countless conflicts.

No global agreement protects tropical forests or regulates forestry and the timber trade. In the absence of an international agreement, the inclusion of policy approaches and positive incentives on issues relating to reducing emissions from deforestation and forest degradation in developing countries (REDD-plus) ${ }^{76}$ in the UNFCCC regime is a significant step forward.

Under the UNFCCC, REDD-plus has the purpose of simultaneously addressing the interlinked issues of sustainable resource exploitation of timber, reducing emissions from deforestation and forest degradation (i.e. slowing, halting and reversing forest cover and carbon loss), generating financial flows from developed countries to developing countries that implement REDD-policies, and building sustainable governance frameworks through participatory requirements for all affected stakeholders, in particular indigenous peoples and local communities. ${ }^{77}$ REDD-activities in developing countries shall be implemented in the context of sustainable development and be reducing poverty, while responding to climate change. Moreover, REDD-activities shall be undertaken in the context of transparent and effective national forest governance structures and shall respect the knowledge and rights of indigenous peoples and members of local communities. ${ }^{78}$ These (and other) elements of REDD-plus are referred to as 'safeguards'. It is also important to note, that only such REDD-activities will be financially rewarded, where the forest-owning country provides the most recent summary of information on how all the safeguards have been addressed and respected before it can receive results-based payments. ${ }^{79}$

75 'Summary of the Roundtable under Workstream 1', 3.

76 See 'Report of the Conference of the Parties on its thirteenth session, held in Bali from 3 to 15 December 2007', Framework Convention on Climate Change, 14 March 2008, FCCC/CP/2007/6/ Add.1, Decision 1/CP.13 Bali Action Plan, which also includes the role of conservation, sustainable management of forests, and enhancement of forest carbon stocks in developing countries in the scope of REDD-plus.

${ }_{78}$ Decision 1/CP.16, Annex I, 2 (c).

79 Decision 9/CP.19 Work programme on results-based finance to progress the full implementation of the activities referred to in decision 1/CP.16, paragraph 70, para. 4 . 
The international framework has be designed with great care, taking into account the power imbalances in the forest sector, unsecured tenure, commercial drivers of deforestation, and conflicts over access to forests and their use and exploitation. If implemented accordingly, REDD-plus has a great potential to strengthen the rights of marginalized groups, such as forest-dependent dwellers and indigenous groups. Further, it has the potential to channel financial resources and development support to needy parts of the population.

However, REDD-plus strategies are challenging in their complex nature. For this reason, it is important to design and implement REDD policies very carefully. A recent study stated:

Forest resource based conflict is one of the issues of great concern in the recent days. People everywhere compete for forest resources they need to survive as they are highly dependent on these resources. Forest is now not limited into the boundary of a country, rather it is now become a matter of international concern because of its role play as climate change mitigation and adaptation. Therefore conflict in forest resource management is not a matter of national, but also become a matter of international community. Timely response of the voices of forest dependent communities is vital to minimize any future risk. ${ }^{80}$

A number of studies point to important implications with regards to REDD+ implementation and conflict management that can be useful for policymakers and practitioners involved in REDD+ strategy designs, as well as other areas of forest management involving outsiders and communities. ${ }^{81}$ If implemented carefully and in accordance with the international framework and guidance, REDD-plus activities can help to reduce the potential for conflicts and to provide resources for basic needs and create necessary social and economic infrastructures. REDD-plus requires good governance, respect for the rule of law and basic human rights, and effective as well as participatory and uncorrupted governance structures.

Having countries cooperating and negotiating the international legal framework for the sustainable management of their forest resources might be one important way to stabilize peaceful situations.

80 Such conflicts could involve: Conflict between community forests and free bounded labour, forest land encroachment, boundary conflicts, conflict among the communities' members who collect forest products from the state-owned forest, state-community conflict; see Dharam Raj Uprety, Harisharan Luintel, and Kamal Bhandari, REDD+ and Conflict: A Case Study of the REDD + Projects in Nepal (The Centre for People and Forest, July 2011), http://www.forestaction.org/app/webroot/js/tinymce/editor/plugins/filemanager/files/REDD-conflict_Report\%20 Dharam.pdf (accessed 28 January 2014). The authors noted: 'There could be several issues which could be potential risk factors to the forest dependent communities such as elite capture on benefits, potential loss of access to forest land, and lack of a system to take voices of poor in decision making,' 26.

${ }_{81}$ Toral Patel et al., 'Predicting Future Conflict under REDD+ Implementation', Forests 4 (10 May 2013), 343-63. 


\section{Conclusions}

Environmental cooperation can help build peace. ${ }^{82}$ Environmental cooperation does not-per se-cause peace, but there are useful catalytic roles for environmental cooperation and in peacemaking — moving along the 'peace continuum' ranging from the absence of violent conflict to the unimaginability of violent conflict. Specific forms of cooperation are designed to build the habit of cooperation, transform interstate bargaining dynamics, and deepen peaceful trans-societal linkages conducive to peaceful cooperation. ${ }^{83}$

Not all environmental cooperation is conducive to peace: the type of cooperation is important. Sustainability remains an important part of the foundation for a lasting peace, therefore environmental cooperation that facilitates more aggressive resource exploitation or continued patterns of unsustainable resource use is problematic. Short-term profits generated by unsustainable resource use may extrapolate political tensions - and may lead to even stronger conflicts in the longer run. Rather, cooperation needs to aim at sustainable resource management and the protection of life-saving ecological functions. The example of the international climate regime and the particular aspect of REDD-plus shows the potential and possibilities of aligning environmental protection and development.

International environmental agreements that are based on sustainable development and equitable allocation of costs and benefits, where environmental commitments are aligned with financial and technology transfer entitlement of those countries that do not dispose of sufficient capacities themselves, may help increase acceptance for such policies among a greater circle of countries.

What is needed, however, is a clear strategy for eco-sensitive sustainable development law in the context of peace. An in-depth look at the different ways in which sustainable development can aid in the process of peace construction, however, is still needed.

Sustainable development, if achieved, contributes decisively to the dissipation, if not the elimination, of several of the primary causes of conflict. If a sustainable development strategy has been successful in terms of the reduction of poverty, the levelling of social inequalities, and the optimum allocation of scarce resources, all while respecting ecological boundaries that are set by life-sustaining ecological functions, then certainly many of the situations that exacerbate conflict between different groups, communities, and nationalities will be avoided. Improving the conditions for environmental and social justice in particular is fundamental to the promotion of peace in a variety of contexts throughout the world.

\footnotetext{
${ }^{82}$ For empirical evidence see Ken Conca and Geoffrey D. Dabelko (eds.), Environmental Peacemaking (Baltimore: Johns Hopkins University Press, 2002).

${ }^{83}$ Conca and Dabelko, 'The Problems and Possibilities of Environmental Peacemaking', 230.
} 
The role of sustainable development is crucial in devising strategies for peace. As Conca aptly noted: 'Creating trust, reciprocity, transparency, cooperative knowledge, shared gains, and habits of cooperation among such entities might simply yield more than just the plundering of resources. ${ }^{84}$ Only if the state is an instrument of genuinely sustainable development, rooted in environmental and social justice, will improving and stabilizing interstate dynamics be likely to transform situations of insecurity. International law can help to nudge states towards a more sustainable, more peaceful future.

${ }^{84}$ Conca and Dabelko (eds.), Environmental Peacemaking, 11. 